\title{
The Atmospheric Corrosion of Structural Steel after Exposure in the Palm Oil Mill Industry Area of Aceh-Indonesia
}

\author{
Muhammad Zulfri ${ }^{1,2}$, Nurdin Ali $^{1,3^{*}}$, Husaini $^{1,3}$, Sri Mulyati ${ }^{1,4}$, and Iskandar Hasanuddin ${ }^{3}$ \\ ${ }^{1}$ Doctoral Program, School of Engineering, Program Pasca Sarjana, Universitas Syiah Kuala, Banda Aceh 23111, Indonesia \\ ${ }^{2}$ Department of Mechanical Engineering, Universitas Samudra, Langsa, 24416, Indonesia \\ ${ }^{3}$ Department of Mechanical \& Industrial Engineering, Universitas Syiah Kuala, Banda Aceh 23111, Indonesia \\ ${ }^{4}$ Department of Chemical Engineering, Universitas Syiah Kuala, Banda Aceh 23111, Indonesia
}

*Corresponding author:

email:nurdin.ali@unsyiah.ac.id

Received: January 1, 2021

Accepted: March 16, 2021

DOI: $10.22146 /$ ijc. 62769

\begin{abstract}
The major cause of early failure in the infrastructures of the palm oil industry in Aceh, Indonesia has been discovered to be the corrosion caused by air pollution from exhaust fumes of the factory plants. Therefore, this research was conducted to analyze the effect of the atmospheric corrosion of the structural steel used in the palm oil mill industry. The five types of structural steel used as samples include strip, l-shape, round bar, plate, and SAPH 610 low carbon steel with a carbon content of $0.18 \%$. These specimens were cleansed from dirt, scaled, and rubbed with sandpaper to achieve a grid of 600, later washed with fresh water and rinsed with alcohol, and subsequently exposed to the environment in PT ASN and PT AKTS palm oil mills for 12 months. Moreover, they were placed on a measuring tray for exposure and the corrosion rate was recorded once a month using the mass loss method in line with the ASTM G50. The results showed the steel construction with a round bar shape was more resistant to atmospheric corrosion and the remaining samples were also observed to be safe and relatively resistant based on their classification as being outstanding $(<1 \mathrm{mpy})$.
\end{abstract}

Keywords: structural steel; air pollution; weight loss; corrosion rate; atmospheric corrosion

\section{- INTRODUCTION}

Indonesia was reported to be the highest palm oilproducing country in the world in 2014 with a plantation area of approximately 10.6 million hectares (Mha) [1]. The province of Aceh had 393,270 hectares of palm plantation area in the year 2016 [2]. The growth of oil palm plantations in Aceh provided a positive impact on the surrounding environment in the form of employment but also led to environmental pollution due to the diffusion of exhaust fumes into the atmosphere as a result of industrial activities. The fumes from the palm oil mill industry contain approximately $45.5 \mathrm{mg} / \mathrm{Nm}^{3}$ of hydrogen sulfide gas [3-4] that can cause atmospheric corrosion.

Industrial fumes have also been proven to decrease the quality of building materials due to the direct and indirect effects of chemical reactions [5-7]. This is observed in the reduction of strength, mass, or aesthetics of metal structures which can further cause a gradual decrease in the mass of the metal material [8-9]. Moreover, thinning of the metal surface caused by corrosion is also the main reason for the premature damage of infrastructures $[6,10]$.

Previous studies have been conducted on the carbon steel corrosion in recycled sour water of 3.5\% $\mathrm{NaCl}$ using the Inductively Coupled Plasma-Mass Spectrometry (ICP-MS) method dipped in different $\mathrm{NaCl}$ solutions [11]. The results showed the corrosion rate decreased when the carbon steel was soaked in recycled sour water due to the passivation effect of the corrosion product [12]. Meanwhile, the $\mathrm{NaCl}$ concentration was observed to have a significant effect on the corrosion rate in all the variations of the solution [13-14]. Similar research was conducted [15] on 
aluminum matrix composite material AlSi10Mg and Silicon Carbide $(\mathrm{SiC})$ at different variations. The results showed the highest corrosion rate was in the materials dipped in $\mathrm{HCl}$ solution with $\mathrm{PH} 1$ while the addition of Silicon Carbide $(\mathrm{SiC})$ was able to reduce the corrosion rate in the aluminum material.

The effect of atmospheric corrosion in the palm oil mill environment was previously researched by Priyotomo et al., and Zulfri et al. [16-17] by determining the corrosion rate of five types of construction steel, classified < 1 mpy [18]. Furthermore, de la Fuente et al. [19] observed carbon steel corrosion under different types of atmosphere such as the industrial, urban, rural, and marine atmosphere [20]. Results showed that marine and industrial atmospheres had significantly worse conditions compared to urban and rural atmospheric conditions [21]. Ridha et al. [22] focused on the atmospheric corrosion mapping of structural metals in the Tsunami area of Aceh in the year 2004 and found a relatively fine resistance for all structural steel exposed in the area which was classified in the outstanding category $(<1 \mathrm{mpy})$. Furthermore, Castaño et al. [23] evaluated corrosion to determine the effect of the total chloride ion and $\mathrm{SO}_{2}$ in line with the wet period of different types of atmospheric conditions using X-ray diffraction (XRD) and scanning electron microscopy-energy dispersive X-ray spectroscopy (SEM-EDS) analysis and found the most aggressive atmospheric corrosion to be based on the chloride content in the air.

The content of active substances in the air such as carbon monoxide (CO), $\mathrm{NO}_{\mathrm{x}}, \mathrm{SO}_{\mathrm{x}}$, and $\mathrm{H}_{2} \mathrm{~S}$ obtained from the processing of fresh oil palm fruit bunches through complex chemical reactions has been discovered to be the cause of atmospheric corrosion in the palm oil mill industry [24]. This means there is a need to study the atmospheric corrosion of structural steel infrastructure at the palm oil mill industry in Aceh province.

This research was, therefore, conducted to assess the effect of atmospheric corrosion on different shapes of construction steel that are used in the palm oil mill industry located on the southwest coast of Aceh province. The study was focused on two different locations, PT Agro Sinergi Nusantara (PT ASN), Bates Puteh, Aceh Jaya, and PT Astra Karya Tanah Subur (PT AKTS), West Aceh.

\section{- EXPERIMENTAL SECTION}

\section{Materials}

This research used five types of structural steel namely strip, 1-shape, round bar, plate, and SAPH 610 low carbon steel with a carbon content of $0.18 \%$ as shown in Fig. 1. The mechanical properties and chemical composition of the samples are presented in Tables 1 and 2.
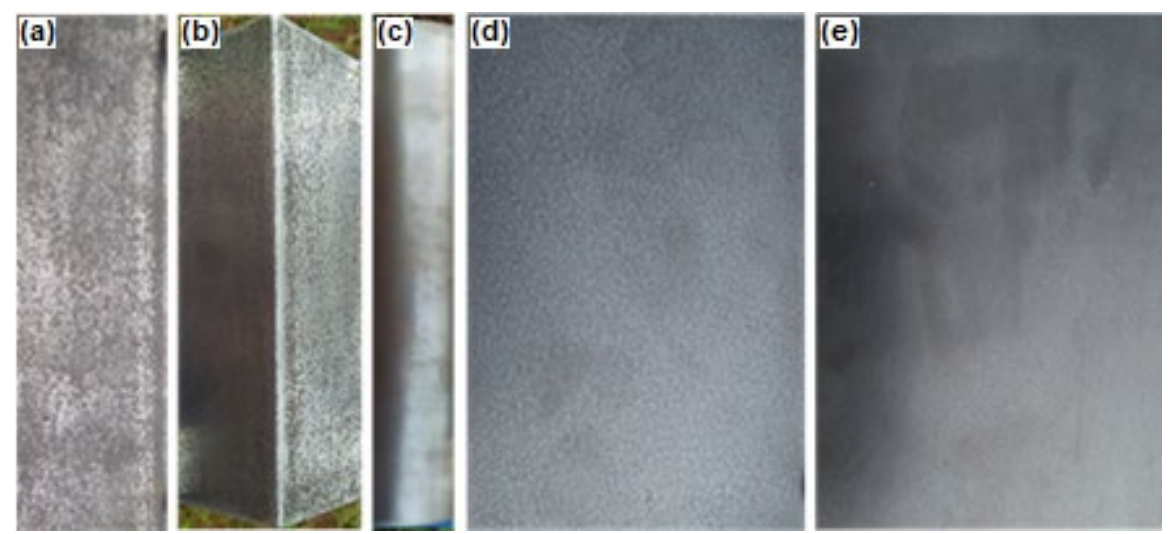

Fig 1. Test Specimen (a) Strip, (b) L-shape, (c) Round bar, (d) Plate, (e) SAPH 610 Low carbon steel

Table 1. Mechanical properties of the samples [14]

\begin{tabular}{cccc}
\hline $\begin{array}{c}\text { Yield Strength } \\
(\mathrm{MPa})\end{array}$ & $\begin{array}{c}\text { Tensile Strength } \\
(\mathrm{MPa})\end{array}$ & $\begin{array}{c}\text { Elongation } \\
(\%)\end{array}$ & $\begin{array}{c}\text { Young Modulus } \\
(\mathrm{GPa})\end{array}$ \\
\hline 356 & 496.5 & 22.68 & 187.8 \\
\hline
\end{tabular}


Table 2. Chemical composition of the samples [14]

\begin{tabular}{cccccccc}
\hline $\mathrm{C}$ & $\mathrm{Si}$ & $\mathrm{Mn}$ & $\mathrm{P}$ & $\mathrm{S}$ & $\mathrm{Ni}$ & $\mathrm{Al}$ & $\mathrm{Fe}$ \\
\hline 0.18 & 0.19 & 0.44 & 0.005 & 0.017 & 0.037 & 0.023 & Balance \\
\hline
\end{tabular}

\section{Procedure}

\section{Sample preparation and exposure}

A total of 30 samples were used, divided into 2 groups of treatment, and each was exposed to an atmospheric environment near PT Agro Sinergi Nusantara (PT ASN) and Astra Karya Tanah Subur (PT AKTS). Each of the specimens of the materials in the research area had 6 coupons and their sizes were in line with the ASTM G 50 standard [25] as shown in Table 3.

The samples were sectioned and subtracted sequentially using silicon carbide abrasive paper with grit from 180 to 600 . They were washed, cleansed with ethyl alcohol, and dried before initially weighed to a precision of 3 decimal places after which an immersion test was conducted to assess the weight loss. The samples were exposed in two locations, PT ASN and PT AKTS, and measurements were obtained monthly for a total of 12 months. In addition to the previous objectives, the corrosion rate of the samples due to weight loss during the immersion test was also analyzed. The test rack for the sample exposure is shown in Fig. 2.

\section{Weight loss measurement}

A quantitative analysis method was applied to determine weight loss and calculate the corrosion rate of the samples. This involved the total exposure of the coupon samples to the atmospheric conditions of PT Agro Sinergi Nusantara (PT ASN) and Astra Karya Tanah Subur (PT AKTS) after which the weight loss was measured as a function of exposure time during and after cleaning from 1 to 12 months according to ASTM G50 [25]. The cumulative weight loss data were arranged in the form of a matrix while the logarithmic form of the graph was constructed to elaborate the relationship between weight loss and immersion time for the designed location. Consequently, the corrosion rate was calculated using Eq. (1) [6-7].

Corrosion Rate $(\mathrm{CR})=\mathrm{K} \frac{\mathrm{W}}{(\mathrm{A} \times \mathrm{t} \times \rho)}$

where $\mathrm{K}$ is the conversion constant for corrosion rate unit, $\mathrm{W}$ is the mass loss in grams, $\mathrm{A}$ is the surface area in $\mathrm{cm}^{2}, \mathrm{t}$ is the exposure period in an hour, and $\rho$ is the density in $\mathrm{g} / \mathrm{cm}^{3}$. Meanwhile, the cross-sectional area was calculated using the following Eq. (2).

$A=2[(1 \times w)+(w \times h)+(h \times l)]$

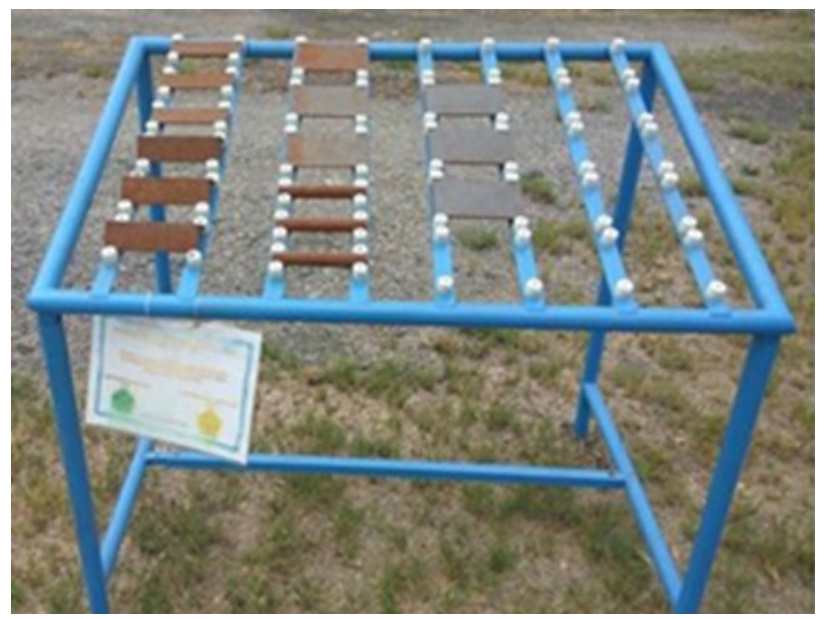

Fig 2. Test specimens on a test rack with samples exposure

Table 3. Numbers and dimensions of specimens used

\begin{tabular}{ccccccc}
\hline \multirow{2}{*}{ No. } & \multicolumn{2}{c}{ Specimens } & \multicolumn{5}{c}{ Size $(\mathrm{mm})$} & Number of \\
\cline { 3 - 6 } & & $\mathrm{L}$ & $\mathrm{W}$ & $\mathrm{T}$ & $\mathrm{D}$ & samples \\
\hline $\mathbf{1}$ & Strip & 150 & 50 & 4 & - & 6 \\
$\mathbf{2}$ & L-shape & 150 & 100 & 3 & - & 6 \\
$\mathbf{3}$ & Round bar & 150 & - & - & 22 & 6 \\
$\mathbf{4}$ & Plate & 150 & 100 & 4 & - & 6 \\
$\mathbf{5}$ & Sheet & 150 & 100 & 4 & - & 6 \\
\hline \multicolumn{2}{l}{ Total samples } & & & & & 30 \\
\hline
\end{tabular}


The relative corrosion resistance was determined in Table 4 through the use of the corrosion rate obtained from Eq. (1).

\section{- RESULTS AND DISCUSSION}

The results of the measurements of the 5 types of construction steel metals used as the atmospheric corrosion test specimens are presented in the form of graphs of corrosion rates and morphological tests with Scanning Electron Microscope to determine the formation of corrosion based on the experiments that were conducted for 12 months.

\section{Corrosion Rate}

The corrosion rate chart was constructed on 5 types of construction metal steel in the oil palm industry. Regarding PT ASN, after exposure during 12 months of investigation, the results show that the chart had a fluctuating trend regarding corrosion and also tended to be influenced by rainfall around the area. The highest corrosion rate was found at $0.56 \mathrm{mpy}$ by the strip construction metal steel in the sixth month of exposure, while the lowest corrosion rate was obtained by the round bar steel at about $0.05 \mathrm{mpy}$.

The strip steel was observed to have the highest average corrosion rate except in the twelfth month where it was surpassed by the plate steel with a corrosion rate of $0.18 \mathrm{mpy}$ as presented in Fig. 3. It was also discovered that the round bar shape and low carbon steel from SAPH 610 were more resistant to atmospheric corrosion than the strip, l-shape, or plate shape steel in PT ASN palm oil mill. which was associated with the higher $\mathrm{Cu}$ content compared to the carbon element [14].

The corrosion rate chart in PT AKTS had a similar trend with PT ASN but an increment was observed in line with an increment in the rainfall. The highest value of approximately $0.58 \mathrm{mpy}$ was recorded for strip steel in the fourth month, September, with the rainfall estimated to be $105 \mathrm{~mm}$, while the lowest corrosion rate of 0.04 mpy, was obtained by the round bar steel in the

Table 4. Relative corrosion resistance based on corrosion rate [18]

\begin{tabular}{lccccc}
\hline Relative Corrosion & \multicolumn{5}{c}{ Approximate Metric Equivalent } \\
\cline { 2 - 5 } Resistance & $\mathrm{mpy}$ & $\mathrm{mm} /$ year & $\mu \mathrm{m} /$ year & $\mathrm{nm} /$ year & $\mathrm{pm} / \mathrm{sec}$ \\
\hline Outstanding & $<1$ & $<0.02$ & $<25$ & $<2$ & $<1$ \\
Excellent & $1-5$ & $0.02-0.1$ & $25-100$ & $2-10$ & $1-5$ \\
Good & $5-20$ & $0.1-0.5$ & $100-500$ & $10-50$ & $5-20$ \\
Fair & $20-50$ & $0.5-1$ & $500-1000$ & $50-100$ & $20-50$ \\
Poor & $50-200$ & $1-5$ & $1000-5000$ & $150-500$ & $50-200$ \\
Unacceptable & $200+$ & $5+$ & $5000+$ & $500+$ & $200+$ \\
\hline
\end{tabular}

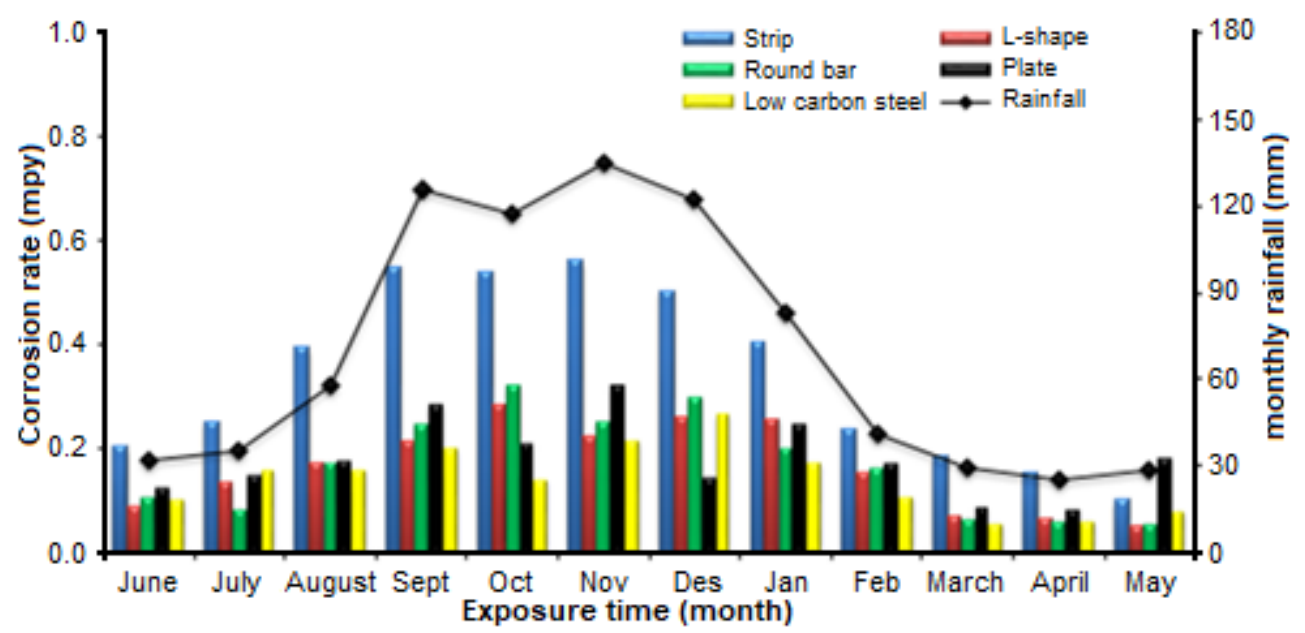

Fig 3. The corrosion rate of construction steel at PT ASN 
twelfth month, May, in which the rainfall was recorded to have reduced drastically to $31 \mathrm{~mm}$.

The lowest corrosion rate in PT AKTS was found for the round bar steel followed by the plate steel as illustrated in Fig. 4. This was attributed to the higher proportion of $\mathrm{Cu}$ in the round bar and a low percentage of carbon in the plate.

\section{Morphology of the Corrosion Product}

The shape of each of the 5 specimens used was evaluated through pre to post sterilization of the products to determine the metal defects or damages due to atmospheric corrosion.

\section{Strip steel}

The results of the morphological test conducted on the steel with the strip profile from different locations of the palm oil mill are presented in Fig. 5. The pre and post sterilization conditions of the test specimens from the corrosion products were measured at $200 \mu \mathrm{m}$ magnification. The samples from the PT ASN area showed the degradation of pitting corrosion in the form of a black color ferrite and pearlite or a black profile on the steel surface. The changes also occurred in the texture of the steel due to the oxidation process during corrosion. The samples in PT AKTS had finer texture on the strip steel shape compared to those in PT ASN with

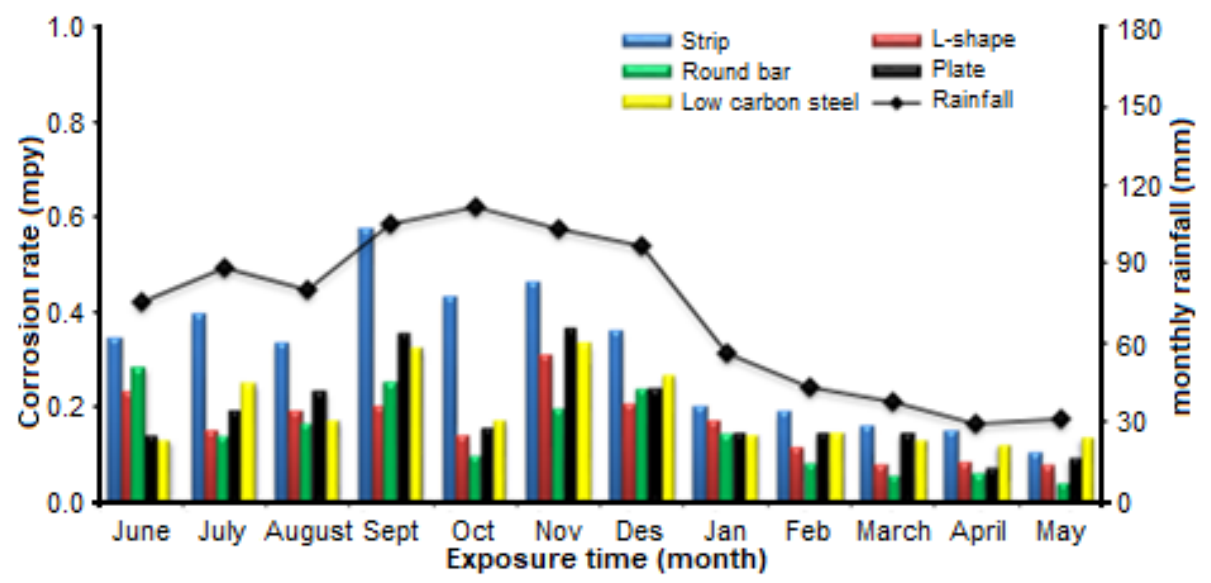

Fig 4. The corrosion rate of construction steel at PT AKTS
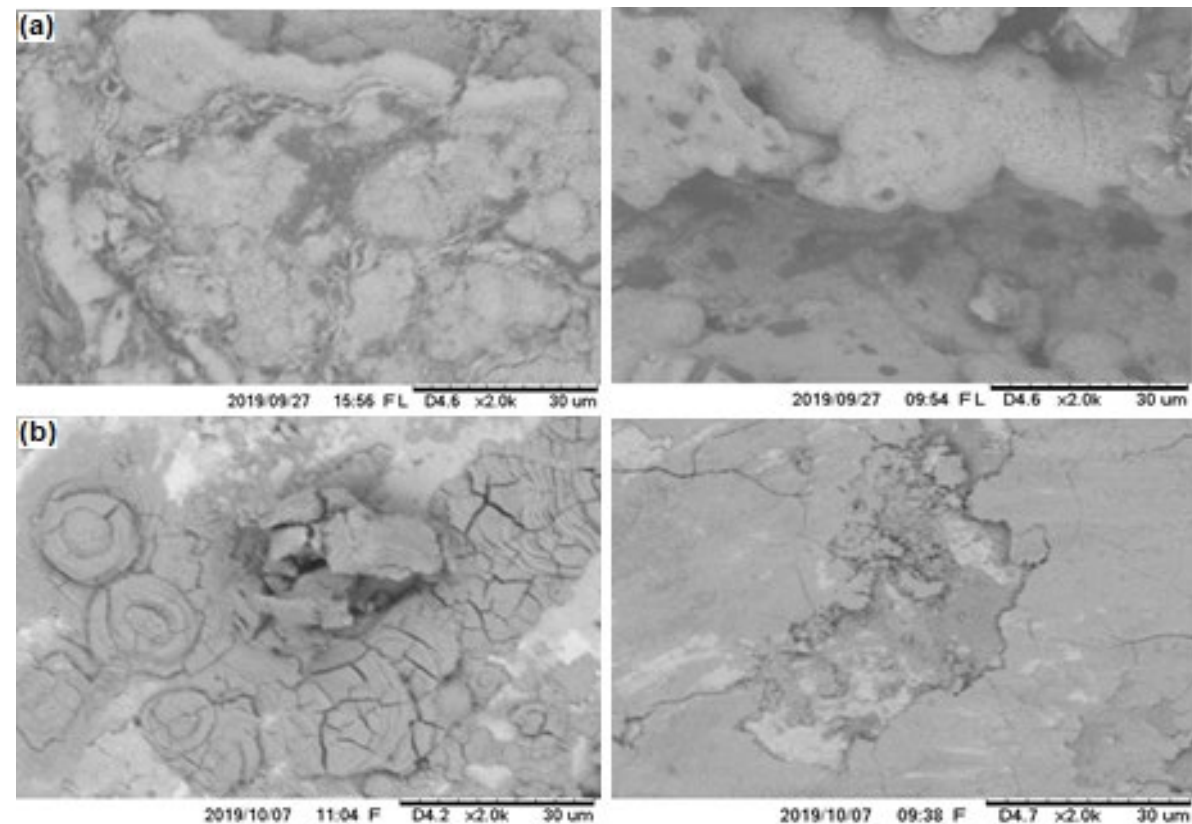

Fig 5. Morphology test for strip steel at PT ASN and PT AKTS using SEM: (a) Pre sterilization, (b) Post sterilization 
a similar shape.

The texture of the strip steel specimens in PT ASN showed significant damages and cracks after poststerilization, thereby, indicating the physical defects due to the atmospheric corrosion while the damage in the specimen from PT AKTS was not too severe, however the surface center was observed to have pitting corrosion.

In conclusion, the strip steel in PT AKTS did not have significant damage on the texture of the surface, however potentially damaging pitting corrosion was observed particularly in the center area of the steel.

\section{L-shape steel}

The corrosion degradation of the L-shape steel after the sterilization process was observed to be significantly different in the two locations. The corrosion in PT ASN was in the form of white ferrite granules while the sample in PT AKTS had a black color. The damages caused to the samples are shown in Fig. 6. The samples in PT ASN were partially damaged due to pitting corrosion with cavities texture or sweet or general corrosion which is usually in the form of holes with no sediment [26]. The corrosion was caused by aggressive chemical elements such as chloride with damaging effects on the passive layer or oxide as well as the presence of $\mathrm{CO}_{2}$, followed by the formation of carbonic acid which lowers the $\mathrm{pH}$. These chemical reactions are presented as $\mathrm{CO}_{2}+\mathrm{H}_{2} \mathrm{O} \leftrightarrow \mathrm{H}_{2} \mathrm{CO}_{3}$ (carbonic acid) and $\mathrm{Fe}+\mathrm{H}_{2} \mathrm{CO}_{3} \rightarrow \mathrm{FeCO}_{3}+\mathrm{H}_{2}$ [20]. The corrosion formed in PTAKTS tended to be uniform due to the distribution of the chemical reactions or electrochemistry on the metal steel surface, which caused thinning and formation of fine grains as shown in Fig. 6 (b) for the post-sterilization of test specimens from the corrosion products [27].

\section{Round bar steel}

The corrosion degradation in the cylindrical steel before the products were cleaned is presented in Fig. 7 and the results showed that it is similar to the cases of the L-shape steel as indicated in Fig. 6. The corrosion profile in PT ASN was ferrite granules while PT AKTS had perlite granules captured at $20 \mu \mathrm{m}$ by the morphology test as shown in Fig. 7.

The corrosion products were cleaned after the test and the results showed that the metal damages in the two locations were caused by pitting corrosion with the damage in PT ASN being more severe than PT AKTS. It was concluded that the round bar steel was more resistant towards corrosion in comparison with the previous two types of steel.

\section{Plate steel}

The corrosion products from the plate steel were indicated by the presence of lumps on the surface of the metal for the samples at PT ASN and PT AKTS, as shown
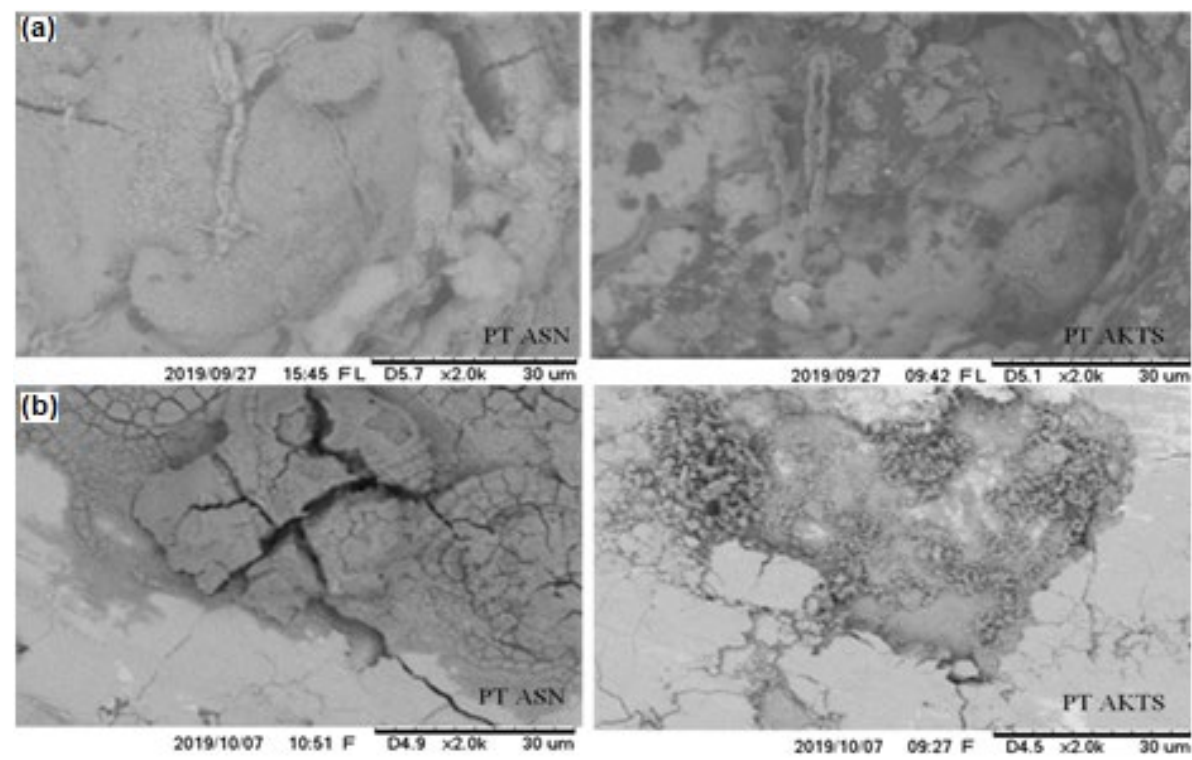

Fig 6. Morphology test for L-shape steel at PT ASN and PT AKTS using SEM: (a) Pre sterilization (b) Post sterilization 

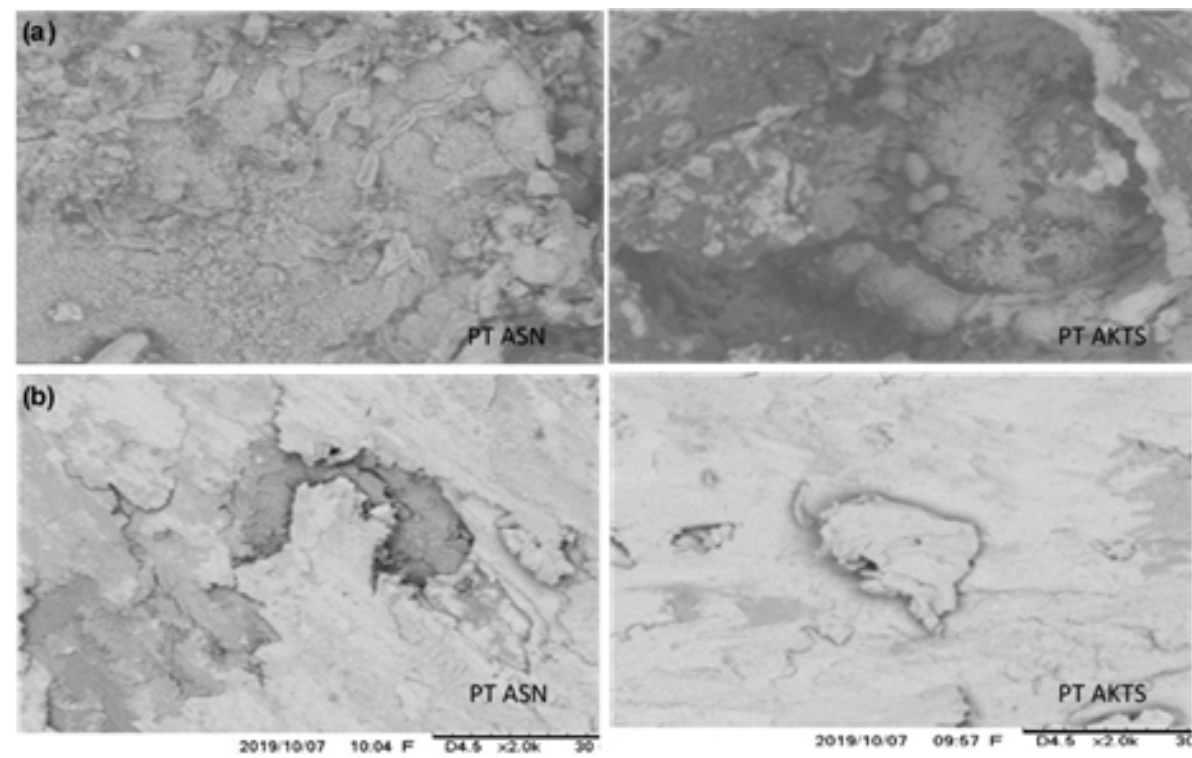

Fig 7. Morphology test for round bar steel at PT ASN \& PT AKTS using SEM: (a) Pre sterilization (b) Post sterilization

in Fig. 8. The corrosion was observed to be uniform due to the electrochemical reaction from the surrounding atmosphere of the oil palm industry as well as the reaction of the $\mathrm{CO}_{2}$ content.

The uniform corrosion had both ferrite and perlite granules formed around the surface of the plate steel in both areas, however, the sample at PT ASN had smaller structures compared to the sample at PT AKTS. In addition, ferrite particles were observed to be partially formed by the granules in PT AKTS. Moreover, post sterilization results showed more severe damages and massive structural cracks in the entire surface of the metal in PT AKTS, while to the metal in PT ASN had finer textural damage with an outside rift.

\section{Sheet steel}

The sheet-shaped steel also had uniform corrosion as shown in Fig. 9 which is common with sheet steel due to its massive surface. Moreover, the corrosion products in PT ASN tended to be perlite granules with high uniformity while those in PT AKTS had more equal ferrite and perlite granules.
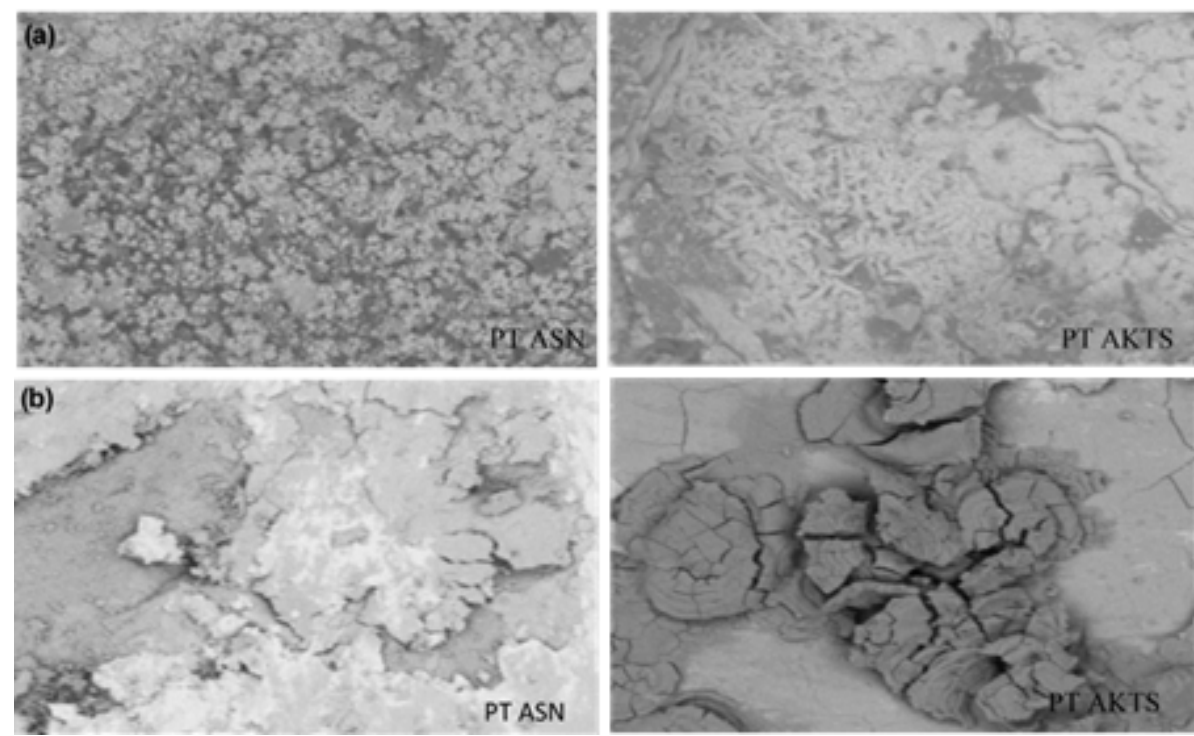

Fig 8. Morphology test for plate steel at PT ASN \& PT AKTS using SEM: (a) Pre sterilization (b) Post sterilization 

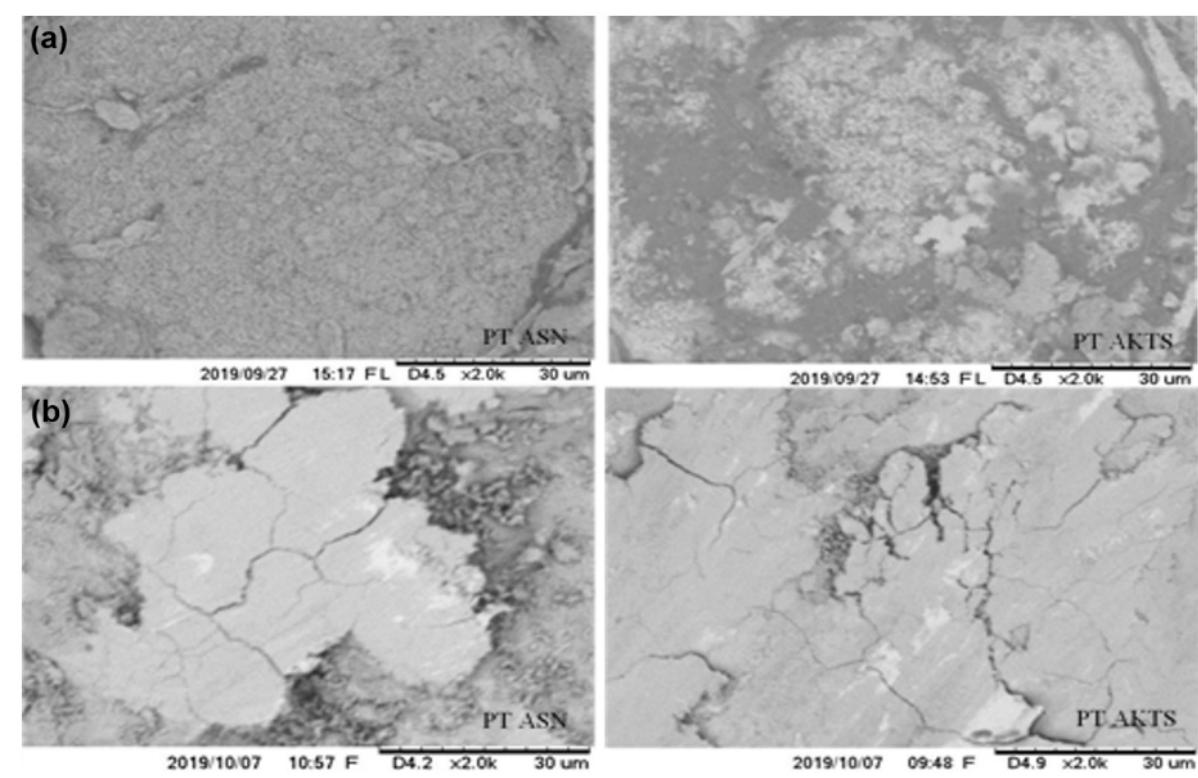

Fig 9. Morphology images of sheet steel at PT ASN \& PT AKTS using SEM: (a) Pre sterilization (b) Post sterilization

The morphology test was also conducted after post sterilization to evaluate the surface structure and the cracks on low carbon steel. The results show that the metals in PT ASN were found to be in poorer conditions compared to those in PT AKTS, which was majorly due to the higher rainfall recorded in PT ASN. The scientific cases are shown in Fig. 4 and 5.

\section{X-Ray Diffraction Analysis}

The morphological test on the pre-and poststerilized samples using SEM was not able to comprehensively explain the corrosion products in the 5 specimens at the two research locations. Therefore, XRD

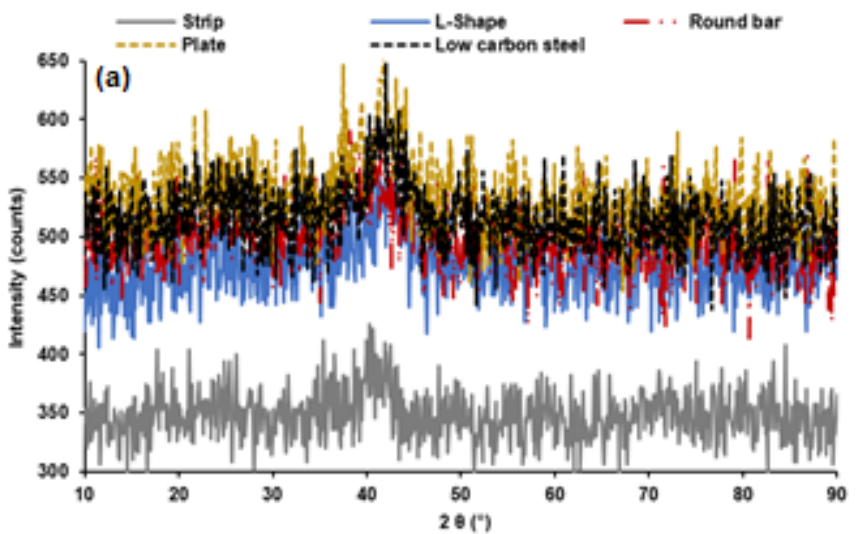

(X-Ray Diffraction) analysis was conducted to see the compound formed by the corrosion process.

The data were collected when the $\mathrm{x}$-ray tube was measured using a voltage of $40 \mathrm{kA}$ and a current of $30 \mathrm{~mA}$ and the results were in the form of a spectrum which states the intensity or counts as a function of the diffraction angle $2 \theta\left({ }^{\circ}\right)$, as shown in Fig. 10.

The results for PT ASN showed that the low carbon and plate steel metals had higher peaks compared to the others as shown in Fig. 10(a). The highest intensity of the low carbon steel was 650 at an angle of $42^{\circ}$ while the plate steel reached 646 at an angle of $37.5^{\circ}$. These peaks indicate the occurrence of corrosion in the test specimens.

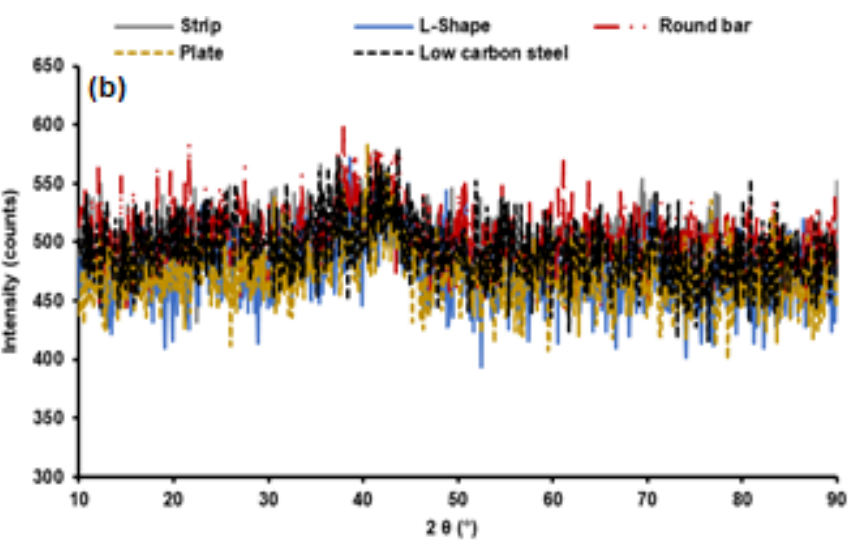

Fig 10. The XRD results of the five types of construction steel metals in the two research locations (a) PT ASN (b) PT AKTS 


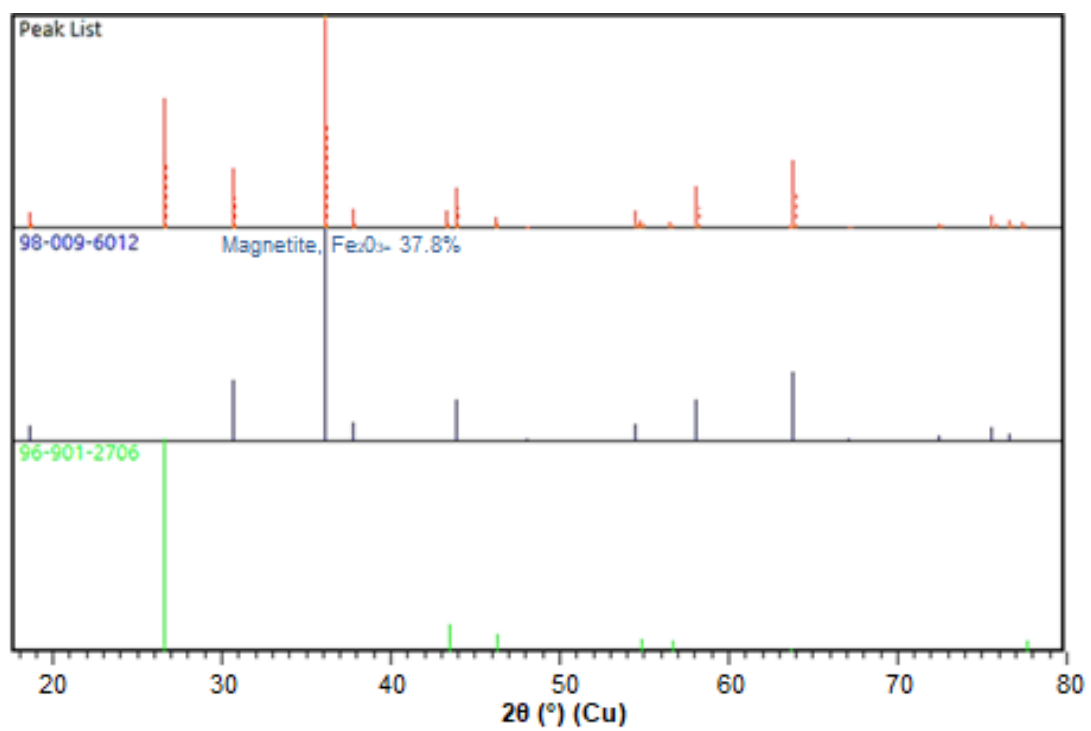

Fig 11. Proving the formation of magnetite $\left(\mathrm{Fe}_{2} \mathrm{O}_{3}\right)$ for strip steel with $37.8 \%$

Further analysis was also conducted using JCPDS software and the findings showed a solid corrosion compound of iron oxide including magnetite and $\mathrm{Fe}_{2} \mathrm{O}_{3}$ at an angle of $2 \theta=32.5^{\circ}, 42^{\circ}$, and $67.8^{\circ}$ for carbon steel and $2 \theta=23.5^{\circ}$ and $37.5^{\circ}$ for strip steel. Meanwhile, the intensity of the other types of steel was reported to be smaller and less striking when compared to the low carbon and strip steel [16]. For PT AKTS, the highest peak was recorded by the cylindrical steel as shown in Fig. 10(b) with the intensity recorded to have reached 598 at $37.9^{\circ}$ followed by the low carbon steel with 566 at $41.9^{\circ}$ and strip steel with 364 at $40.1^{\circ}$. An example of the magnetite $\left(\mathrm{Fe}_{2} \mathrm{O}_{3}\right)$ formed on the strip shape steel is presented in Fig. 11.

The high peaks at PT ASN are due to the reaction of the corrosion products such as iron oxide $\left(\mathrm{FeO}, \mathrm{Fe}_{2} \mathrm{O}_{3}\right.$, and $\left.\mathrm{Fe}_{3} \mathrm{O}_{4}\right)$, goethite $(\alpha-\mathrm{FeOOH})$, and lepidocrocite $(\gamma-$ $\mathrm{FeOOH}$ ) [28-30].

\section{- CONCLUSION}

The analysis of five different construction steel metals in two research locations showed that strip plate steel had the highest corrosion rates of 0.56 on the sixth month and 0.57 mpy on the fourth month of evaluation after the samples were exposed to the atmospheric conditions of PT ASN and PT AKTS areas, respectively. Meanwhile, the lowest corrosion rate was recorded for the round bar steel at a value of $0.04 \mathrm{mpy}$ in PT AKTS and 0.05 mpy in the PT ASN area during the twelfth month.
Moreover, both pitting and uniform corrosions were discovered in the products and the variations of the steel metal forms were found to be most affected by the speed of corrosion rate which tended to be higher for the strip plate steel and conventional plate. The results after 1 (one) year of exposure showed that the cylindrical steel was more resistant to atmospheric corrosion and damage while the others tended to be safe, relatively resistant, and classified to be outstanding materials since their corrosion rates were $<1 \mathrm{mpy}$.

\section{- ACKNOWLEDGMENTS}

The authors express their gratitude to the Directorate of Research and Community Service Kemenristek Dikti Contract No.136/UN54.6/LT/2018 for funding this research through the Higher Education Collaboration Research scheme of 2018. The authors also appreciate Dr.-Eng. Deni Shidqi Khaeruddin of the Indonesian Institute of Sciences, Serpong, Banten 15314, Indonesia for analyzing the XRD data.

\section{- AUTHOR CONTRIBUTIONS}

$\mathrm{MZ}$ and NA designed, experimented, and wrote the manuscript, $\mathrm{H}$ and $\mathrm{SM}$ supervised the experiment and article writing while IH proofread the manuscript. All authors agreed to the final version of this manuscript.

\section{- REFERENCES}

[1] Khatiwada, D., Palmén, C., and Silveira, S., 2021, Evaluating the palm oil demand in Indonesia: 
production trends, yields, and emerging issues, Biofuels, 12 (2), 135-147.

[2] Hanafiah, J., 2016, Palm oil expands in Aceh, Mongabay Series: Indonesian Forests, Indonesian Palm Oil, Leuser Ecosystem, https://news.monga bay.com/2016/01/palm-oil-expands-in-aceh/.

[3] Syahza, A., 2019, The potential of environmental impact as a result of the development of palm oil plantation, Manage. Environ. Qual., 30 (5), 1072-1094.

[4] Badrun, Y., 2010, Emisi udara industry pengolahan kelapa sawit di kabupaten Rokan Hilir, Photon: Jurnal Sain Dan Kesehatan, 1 (1), 23-29.

[5] Roberge, P.R., 2000, Handbook of Corrosion Engineering, $2^{\text {nd }}$ Ed, McGraw-Hill, New York.

[6] Revie, R.W., and Uhlig H.H., 2008, Corrosion and Corrosion Control: An Introduction to Corrosion Science and Engineering, $4^{\text {th }}$ Ed., John Wiley \& Sons, Inc., Canada.

[7] Ali, N., Fulazzaky, M.A., Mustapa, M.S., Ghazali, M.I., Ridha, M., and Sujitno, T., 2014, Assessment of fatigue and corrosion fatigue behaviours of the nitrogen ion implanted Cp Ti, Int. J. Fatigue, 61, 184-190.

[8] Ali, N., Putra, T.E., Iskandar, V.Z., and Ramli, M., 2020, A simple empirical model for predicting weight loss of mild steel due to corrosion in $\mathrm{NaCl}$ solution, Int. J. Automot. Mech. Eng., 17 (1), 7784-7792.

[9] Martinez, C., Briones, F., Villarroel, M., and Vera, R., 2018, Effect of atmospheric corrosion on the mechanical properties of SAE 1020 structural steel, Materials, 11 (4), 591.

[10] Ghahari, M., Rashid-Nadimi, S., and Bemana, H., 2019, Metal-air desalination battery: Concurrent energy generation and water desalination, J. Power Sources, 412, 197-203.

[11] Ismail. A., Mahari, S., Shamsuddin, F., Hasan, N., and Ramli N., 2019, Evaluation of corrosion product formed on carbon steel in recycled sour water of overhead system, Int. J. Integr. Eng., 11 (7), 95-101.

[12] Ismail, A., and Adan, N.H., 2014, Effect of Oxygen Concentration on Corrosion Rate of Carbon Steel in Seawater, Am. J. Eng. Res., 03 (1), 64-67.

[13] Möller, H., Boshoff, E.T., and Froneman, H., 2006, The corrosion behaviour of a low carbon steel in natural and synthetic seawaters, J. South. Afr. Inst. Min. Metall., 106 (8), 585-592.

[14] Ali, N., Putra, T.E., Husaini, Iskandar, V.Z., and Thalib, S., 2019, Corrosion rate of mild steel for construction materials in various $\mathrm{NaCl}$ concentrations, IOP Conf. Ser.: Mater. Sci. Eng., 536, 012015.

[15] Tjahjanti, P.H., Darminto, Nugroho, W.H., and Ganda, A.N.F., 2019, Study of corrosion penetration rate on composite materials EN AC43100 (AlSi10Mg (b)) + SiC ${ }^{*}$, Int. J. Integr. Eng., 11 (6), 1-9.

[16] Priyotomo, G., Nuraini, L., Prifiharni, S., Royani, A., Sundjono, Gunawan, H., and Zheng, M., 2020, Atmospheric corrosion behavior of carbon steel and galvanized steel after exposure in Eretan and Ciwaringin, West Java Province, Indonesia, Indones. J. Chem., 20 (5), 1032-1043.

[17] Zulfri, M., Ali, N., Husaini, Fonna, S., Huzni, S., Mulyati, S., and Cut, B., 2019, Atmospheric corrosion assessment of structural steel exposed in the environment of palm oil processing (PKS) industry around coastal zone, IOP Conf. Ser.: Mater. Sci. Eng., 536, 012016.

[18] Marzorati, S., Verotta, L., and Trasatti, S.P., 2019, Green Corrosion Inhibitors from Natural Sources and Biomass Wastes, Molecules, 24 (1), 48.

[19] De la Fuente, D., Alcántara, J., Chico B., Díaz, I., Jiménez, J.A., and Morcillo, M., 2016 Characterisation of rust surfaces formed on mild steel exposed to marine atmospheres using XRD and SEM/Micro-Raman techniques, Corros. Sci., 110, 253-264.

[20] Nuraini, L., Prifiharni, S., Priyotomo, G., Sundjono, Gunawan, H., and Purawiardi, I., 2018, Atmospheric corrosion performance of different steels in early exposure in the coastal area region West Java, Indonesia, AIP Conf. Proc., 1964, 020040.

[21] Shafiei, E., Zeinali, M., Nasiri, A., Charroostaei, H., and Gholamalian, M.A., 2014, A brief review on the atmospheric corrosion of mild steel in Iran, Cogent Eng., 1 (1), 990751. 
[22] Ridha, M., Fonna, S., Huzni, S., Supardi, J., and Ariffin, A.K., 2013, Atmospheric corrosion of structural steels exposed in the 2004 tsunami-affected areas of Aceh, Int. J. Automot. Mech. Eng., 7, 1014-1022.

[23] Castaño, J.G., Botero, C.A., Restrepo, A.H., Agudelo, E.A., Correa, E., and Echeverría, F., 2010, Atmospheric corrosion of carbon steel in Colombia, Corros. Sci., 52 (1), 216-223.

[24] Dugstad, A., Halseid, M., and Morland, B., 2013, Effect of $\mathrm{SO}_{2}$ and $\mathrm{NO}_{2}$ on corrosion and solid formation in dense phase $\mathrm{CO}_{2}$ pipelines, Energy Procedia, 37, 2877-2887.

[25] ASTM G50-10, 2010, Standard Practice for Conducting Atmospheric Corrosion Tests on Metal, ASTM International, Barr Harbor Drive, West Conshohocken, PA, 1-15.

[26] Antunes, R.A., Ichikawa, R.U., Martinez, L.G., and Costa, I., 2014, Characterization of corrosion products on carbon steel exposed to natural weathering and to accelerated corrosion tests, Int. J. Corros., 2014, 419570.

[27] Pessu, F.M, Barker, R., and Neville A., 2016, Understanding pitting corrosion behavior of X-65 carbon steel in $\mathrm{CO}_{2}$-saturated environments: The temperature effect, Corrosion, 72 (1), 78-94.

[28] Montoya, P., Marín, T., Echavarría, A., and Calderón, J.A., 2013, Influence of anion and $\mathrm{pH}$ on the electrochemical Co-deposition and transformation of iron oxy-hydroxide, Int. J. Electrochem. Sci., 8, 12566-12579.

[29] Morcillo, M., de la Fuente, D., Díaz, I., and Cano, H., 2011, Atmospheric corrosion of mild steel, Rev. Metal., 47 (5), 426-444.

[30] Thalib, S., Ikhsan, M., Fonna, S., Huzni, S., and Syahrir, 2018, Identification of corrosion product on medium carbon steel under the exposure of Banda Aceh's atmosphere, IOP Conf. Ser.: Mater. Sci. Eng., 352, 012004. 